(c) American Dairy Science Association, 2005.

\title{
Pregnancy Rates in Lactating Dairy Cows After Presynchronization of Estrous Cycles and Variations of the Ovsynch Protocol*
}

\author{
M. A. Portaluppi and J. S. Stevenson \\ Department of Animal Sciences and Industry, Kansas State University, Manhattan 66506-0201
}

\begin{abstract}
Our objectives were to determine pregnancy rates after altering times of the second GnRH injection, insemination, or both in a combined Presynch + Ovsynch protocol, to accommodate once-daily lockup of dairy cows. Lactating dairy cows $(\mathrm{n}=665)$ from 2 dairy herds in northeastern Kansas were studied. Cows ranged from 24 to $44 \mathrm{~d}$ in milk (DIM) at the start of the Presynch protocol, which consisted of 2 injections of $\mathrm{PGF}_{2 \alpha}$ $14 \mathrm{~d}$ apart, with the second injection given $12 \mathrm{~d}$ before initiating the Ovsynch protocol. Cows were blocked by lactation number and assigned randomly to 3 treatments consisting of variations of the Ovsynch protocol. Cows in 2 treatments received injections of GnRH $7 \mathrm{~d}$ before and $48 \mathrm{~h}(\mathrm{G} 48)$ after the $\mathrm{PGF}_{2 \alpha}$ injection. Timed $\mathrm{AI}$ (TAI) was conducted at the time of the second GnRH injection (G48 + TAI48) or $24 \mathrm{~h}$ later (G48 + TAI72). Cows in the third treatment received the injections of GnRH $7 \mathrm{~d}$ before and at $72 \mathrm{~h}$ after $\mathrm{PGF}_{2 \alpha}$ and were inseminated at the time of the second $\mathrm{GnRH}$ injection (G72 + TAI72). Pregnancy was diagnosed weekly by palpation per rectum of uterine contents on d 40 or 41 after TAI. Pregnancy rates differed between herds, but they were consistently greater for G72 + TAI72 than for G48 + TAI48 and G72 + TAI72. Subsequent calving rates were consistent with differences in initial TAI pregnancy rates. Pregnancy loss was least for cows on the G72 + TAI72 treatment. Body condition scores (BCS) ranged from 1.0 to 4.0 when assessed on Monday of the breeding week. An interaction of BCS and herd was detected in which cows in herd 1 having poorer BCS $(<2.25)$ had greater pregnancy rates than cows of greater BCS ( $\geq 2.25$ ), whereas the reverse was true in herd 2 in which overall pregnancy rates were greater. We concluded that inseminating at 48 or $72 \mathrm{~h}$ after $\mathrm{PGF}_{2 \alpha}$, when $\mathrm{GnRH}$ was administered at $48 \mathrm{~h}$ after $\mathrm{PGF}_{2 \alpha}$, produced fewer pregnancies than inseminating and injecting $\mathrm{GnRH}$ at $72 \mathrm{~h}$ after $\mathrm{PGF}_{2 \alpha}$ for cows whose
\end{abstract}

\footnotetext{
Received October 11, 2004.

Accepted December 14, 2004.

Corresponding author: J. S. Stevenson; e-mail: jss@ksu.edu. *Contribution number 05-090-J from the Kansas Agricultural Experiment Station, Manhattan.
}

estrous cycles were synchronized before initiating this variant of the Ovsynch protocol.

(Key words: Ovsynch, Presynch, pregnancy rate)

Abbreviation key: CL = corpus luteum, G48 + TAI48 $=\mathrm{GnRH}$ injection and TAI at $48 \mathrm{~h}$ after $\mathrm{PGF}_{2 \alpha}$, G48 + TAI72 $=$ GnRH injection at $48 \mathrm{~h}$ and TAI at 72 $\mathrm{h}$ after $\mathrm{PGF}_{2 \alpha}, \mathbf{G 7 2}+\mathbf{T A I 7 2}=\mathrm{GnRH}$ injection and TAI at $72 \mathrm{~h}$ after $\mathrm{PGF}_{2 \alpha}$, Ovsynch $=$ injection of $\mathrm{GnRH}$ $7 \mathrm{~d}$ before and $48 \mathrm{~h}$ after PGF $_{2 \alpha}$ before TAI, P4 = progesterone, Presynch $=2$ injections of $\mathrm{PGF}_{2 \alpha} 14$ $\mathrm{d}$ apart with the second injection given $12 \mathrm{~d}$ before initiating the Ovsynch protocol, $\mathbf{T A I}=$ timed AI.

\section{INTRODUCTION}

Estrus-detection efficiency (AI submission rate) is one of the most important factors limiting reproductive performance of dairy cows. Advances in genetics and management have changed the dairy industry in the face of increasing numbers of cows per herd (Lucy, 2001). The shift in herd size has created a new problem for reproductive management of dairy cows. Traditional methods of detecting estrus are inefficiently applied in large dairy herds in which the number of cows managed per worker has increased, resulting in decreased accuracy and efficiency of detecting estrus. According to recent studies, $<50 \%$ of the lactating dairy cows were detected in estrus (Senger, 1994; Washburn et al., 2002), resulting in prolonged interinsemination intervals (Stevenson et al., 1983) and less profit for the dairy producer.

One way to manage the decline in reproductive performance of dairy herds is to apply methods to control follicular dynamics and luteal life span. Application of the Ovsynch protocol [injection of GnRH $7 \mathrm{~d}$ before and $48 \mathrm{~h}$ after $\mathrm{PGF}_{2 \alpha}$ before timed $\mathrm{AI}$ (TAI)] allows for synchronization of follicular development, luteal regression, and time of ovulation with minimal need for detection of estrus (Pursley et al., 1995, 1997a,b). Conception rates after TAI in some studies are less than those when AI is based on detected estrus (Burke et al., 1996; Pursley et al., 1997a,b; Stevenson et al., 1999; Jobst et al., 2000), but because more cows are inseminated, depending on estrus detection or AI sub- 
mission rates, pregnancy rates are usually greater after TAI (Pursley et al., 1997a,b; Cartmill et al., 2001b).

Stage of the estrous cycle at which the Ovsynch protocol is initiated influenced its effectiveness. Initiating the protocol in cows during early to middiestrus (d 5 and 12) produced greater pregnancy rates than those in which the Ovsynch protocol was initiated on other days of the estrous cycle (Vasconcelos et al., 1999). One way to target the initiation of this protocol during the most favorable stage of the estrous cycle is to presynchronize the estrous cycles of cows before the first injection of GnRH of the Ovsynch protocol (Moreira et al., 2001; El-Zarkouny et al., 2004). Use of 2 injections of $\mathrm{PGF}_{2 \alpha}$, administered $14 \mathrm{~d}$ apart, with 12 intervening $\mathrm{d}$ before initiation of Ovsynch (Presynch), constitutes a practical and relatively inexpensive method for presynchronization. More than $70 \%$ of the cows began the Ovsynch protocol during early- to middiestrus (between $\mathrm{d} 5$ and 12) when Presynch was applied before Ovsynch, compared with 53\% of the cows treated with Ovsynch at random stages of the cycle (El-Zarkouny et al., 2004).

Establishing the optimal time for TAI after the second GnRH injection of the Ovsynch protocol was part of the original Ovsynch study. Lactating dairy cows were inseminated at the same time as $\mathrm{GnRH}$ was administered ( $48 \mathrm{~h}$ after $\mathrm{PGF}_{2 \alpha}$ ) or at $8,16,24$, or $32 \mathrm{~h}$ after GnRH (Pursley et al., 1998). Although pregnancy rates were similar for cows inseminated from 0 to $24 \mathrm{~h}$, and cows inseminated at $32 \mathrm{~h}$ after $\mathrm{GnRH}$ had reduced pregnancy rates, pregnancy outcomes at 0 to $32 \mathrm{~h}$ produced a quadratic response curve, indicating that insemination at $16 \mathrm{~h}$ was optimal. Inseminating at 16 $\mathrm{h}$ after $\mathrm{GnRH}$, however, is inconvenient because it may not coincide with once-daily lockup of cows at the feed bunk after the morning milking. Most importantly, timing of AI for cows pretreated with the Presynch protocol before Ovsynch has not been addressed.

When we consider the increased proportion of cows between $\mathrm{d} 5$ to 12 of the estrous cycle after a combined Presynch + Ovsynch protocol and more uniformity of follicular dynamics in synchrony with luteal demise after $\mathrm{PGF}_{2 \alpha}$, timing of the second GnRH injection and TAI may be different from inseminations made between 0 and $24 \mathrm{~h}$ after $\mathrm{GnRH}$ in the Ovsynch protocol. Therefore, the objective of the present experiment was to determine pregnancy rates after altering times of the second GnRH injection, insemination, or both in a combined Presynch + Ovsynch protocol, to correspond with once-daily lockup of dairy cows.

\section{MATERIALS AND METHODS}

\section{Herd Management}

Lactating dairy cows $(\mathrm{n}=715)$ calving between July 2002 and May 2003 were used at 2 cooperating com- mercial dairy herds in northeastern Kansas. The herds were composed of 628 to 696 cows and were milked 3 times daily, with rolling herd averages ranging from 11,800 to $12,400 \mathrm{~kg}$ of milk. Cows were housed in either 2- or 4-row free-stall barns consisting of feed-line head lockups and free stalls bedded with sand, equipped with sprinklers and fans above the feed line and fans above the free stalls. Cows were fed a TMR at least twice daily, consisting of corn silage, chopped alfalfa, whole cottonseed, corn or milo grain, soybean meal, vitamins, and minerals. Cows had free access to fresh water ad libitum in open tanks at 3 or more locations in each 100-cow pen.

\section{Experimental Design}

Cows were grouped into breeding clusters every 2 wk within each herd. The DIM ranged from 24 to 44 $\mathrm{d}$ at the start of the Presynch protocol. All cows received two 25 -mg injections of $\mathrm{PGF}_{2 \alpha}$ (5 mL of Lutalyse; Pharmacia Animal Health, Kalamazoo, MI) 14 d apart, with a second injection given $12 \mathrm{~d}$ before initiating the Ovsynch protocol. Cows were blocked by lactation number (1 vs. $2+)$ and assigned randomly to 3 treatments, consisting of variations in the timing of $\mathrm{GnRH}$ and $\mathrm{AI}$ after the $\mathrm{PGF}_{2 \alpha}$ injection of the Ovsynch protocol. Inseminations were performed between September 2002 and June 2003. Insemination was carried out between 65 and 79 DIM in one herd and between 58 and 79 DIM in the second herd. Treatments were initiated every 2 wk within herd, with cows from each herd being inseminated on alternate weeks. Body condition score $(1=$ thin to $5=$ fat $)$ was evaluated on Monday of the breeding week.

Treatment protocols are illustrated in Figure 1. Cows in 2 treatments received one $100-\mu \mathrm{g}$ injection of GnRH (2 mL of Fertagyl; Intervet, Millsboro, DE) $7 \mathrm{~d}$ before and $48 \mathrm{~h}$ after a $\mathrm{PGF}_{2 \alpha}$ injection. Fixed TAI occurred concurrent with the second $\mathrm{GnRH}$ injection (G48 + TAI48) or $24 \mathrm{~h}$ later (G48 + TAI72). Cows in the third treatment received the first injection of GnRH 7 $\mathrm{d}$ before, and the second injection of $\mathrm{GnRH}$ at $72 \mathrm{~h}$ after PGF $_{2 \alpha}$, concurrent with TAI $($ G72 + TAI72). All cows in the experiment were treated and inseminated during the morning hours (0700 to $1000 \mathrm{~h}$ ) after milking, while restrained in feed-line head lockups. Cows that were detected in estrus before their scheduled TAI were not inseminated until their scheduled breeding time. Pregnancy was diagnosed weekly by palpation per rectum of uterine contents on d 40 (herd 1) or 41 (herd 2) by the same veterinary practitioner.

In one herd (herd 2) during November to January, representing 5 breeding clusters of 117 cows, observations of sexual behavior were recorded based on daily- 


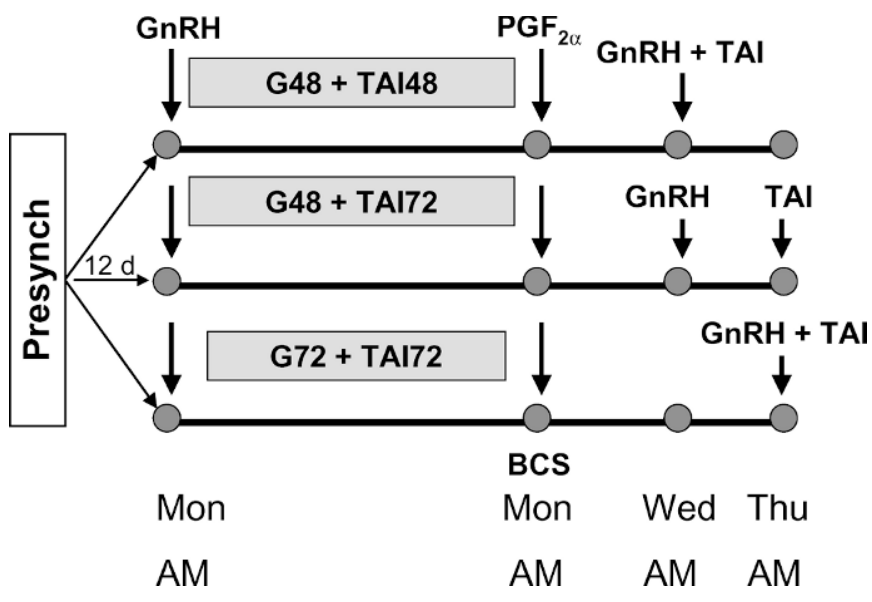

Figure 1. All cows received 2 injections of $\mathrm{PGF}_{2 \alpha} 14 \mathrm{~d}$ apart (Presynch), with the second injection given $12 \mathrm{~d}$ before initiating one of 3 Ovsynch-like protocols. All injections and timed AI (TAI) were administered while cows were restrained in feed-line lockups $(0700$ to $1000 \mathrm{~h}$ ) after the first milking of the day. TAI = Timed AI.

assessed chalk rubs and visually detected standing events.

\section{Statistical Analyses}

Various analyses were performed using ANOVA of the binomial variables of interest (procedure GENMOD; SAS Inst., Inc., Cary, NC). To assess pregnancy rate, calving rate, and pregnancy loss between TAI and calving for cows that conceived at the treatment TAI, the model consisted of treatment $(\mathrm{n}=3)$, herd $(\mathrm{n}=2)$, lactation number (1 vs. $2+)$, BCS ( $<2.25$ vs. $\geq 2.25$ ), breeding cluster ( $\mathrm{n}=11$ in herd 1 and $\mathrm{n}=$ 22 in herd 2), and 2-way interactions with DIM as a covariate. A priori contrasts of treatment means included G72 + TAI72 vs. the other 2 treatments, and G72 + TAI72 vs. G48 + TAI48. Further individual comparisons of least squares means were made by $\chi^{2}$ within procedure GENMOD.

\section{RESULTS AND DISCUSSION}

To our knowledge, this is the first study to determine the time for AI after applying a combined Presynch + Ovsynch protocol. Results for 665 of 715 cows are summarized. Pregnancy outcomes for 50 cows assigned to treatments were not available because treatments were not completed or culling occurred before TAI or before pregnancy status was determined.

Of 117 cows in herd 2 in which estrual activities were recorded, 64 cows $(54.7 \%)$ were detected in estrus. Of the 64 cows detected in estrus, $33(51.6 \%)$ were detected on the second day after $\mathrm{PGF}_{2 \alpha}$, whereas 31 cows
(48.4\%) were detected on the third day. For cows given $\mathrm{GnRH}$ at $48 \mathrm{~h}$ after $\mathrm{PGF}_{2 \alpha}$ (combined treatments in which $\mathrm{GnRH}$ was given at $48 \mathrm{~h}), 22$ of $35(62.9 \%)$ were detected on that day and the remainder on the next day. For cows given GnRH at $72 \mathrm{~h}, 11$ of 29 cows $(38.9 \%)$ were in estrus on the second day, and the remainder were in estrus on the next day. More $(P<$ 0.05 ) cows given $\mathrm{GnRH}$ at $48 \mathrm{~h}$ were in estrus on the second day compared with those not given $\mathrm{GnRH}$ (62.9\% vs. $38.9 \%$, respectively), whereas the reverse was true on the third day ( $37.1 \%$ vs. $61.1 \%$, respectively).

Effects of treatment on pregnancy rates are summarized in Table 1 . Herds differed $(P<0.01)$ in overall pregnancy rates [herd $1=16.2 \%(\mathrm{n}=235)$ vs. herd $2=$ $31.2 \%(\mathrm{n}=430)$ ]. In both herds, however, pregnancy rates were consistently greater $(P<0.05)$ for $\mathrm{G} 72+$ TAI72 than for the other 2 treatments combined. Further, G72 + TAI72 differed from each treatment individually $(P=0.05$; G48 + TAI48) or tended $(P=0.06)$ to differ (G48 + TAI72).

First-lactation cows $(\mathrm{n}=267)$ tended $(P<0.10)$ to have greater pregnancy rates $(28.5 \%$ vs. $24.1 \%)$ than older cows $(\mathrm{n}=398)$. In contrast, other studies using 1 (Cartmill et al., 2001a) or 2 injections of $\mathrm{PGF}_{2 \alpha}$ (ElZarkouny et al., 2004) before the Ovsynch protocol, first-lactation cows were reported to be more fertile at first AI than older cows. Older cows have, in some instances, a greater incidence of metabolic and reproductive problems that may reduce their pregnancy outcomes when inseminated as part of the Ovsynch protocol (Tenhagen et al., 2004). In contrast, using a modified Presynch protocol in which 2 injections of $\mathrm{PGF}_{2 \alpha}$ were given $14 \mathrm{~d}$ apart, with the second injection of $\mathrm{PGF}_{2 \alpha}$ administered $14 \mathrm{~d}$ before Ovsynch, Navanukraw et al. (2004) did not detect an effect of lactation number on pregnancy rate after TAI.

The BCS on Monday of the breeding week ranged from 1.0 to 4.0 in both herds, and influenced the reproductive outcomes of dairy cows differently in the 2 herds in this experiment. Although BCS $(2.2 \pm 0.03$ vs. $2.3 \pm 0.02)$ was slightly less $(P=0.05)$ in herd 1 than herd 2, the physiological significance of that difference is questionable. An interaction $(P<0.05)$ of BCS and herd, however, was detected in which cows in herd 1 of poorer BCS $(<2.25)$ had greater pregnancy rates than cows of greater BCS $(\geq 2.25 ; 19 \%$ vs. $13 \%$, respectively), whereas the reverse was true in herd 2 ( $25 \%$ vs. $35 \%$, respectively). Most studies reported a positive relationship between BCS and fertility for cows when the Ovsynch protocol was applied (Cartmill et al., 2001a; Yamada et al., 2003). For example, cows having BCS $>3$ at initiation of the Ovsynch protocol 
Table 1. Unadjusted mean percentages for pregnancy rates at 40 to $41 \mathrm{~d}$ after timed AI (TAI), calving rates, and pregnancy loss in lactating dairy cows.

\begin{tabular}{llllc}
\hline Treatment & Herd & $\begin{array}{l}\text { Pregnancy } \\
\text { rate }^{2}\end{array}$ & $\begin{array}{l}\text { Calving } \\
\text { rate }^{3}\end{array}$ & $\begin{array}{l}\text { Pregnancy } \\
\text { loss }^{4}\end{array}$ \\
\hline G48 + TAI48 & 1 & $12.5(80)$ & $12.5(80)$ & $0.0(10)$ \\
G48 + TAI72 & $\frac{2}{\text { Total }}$ & $\frac{28.4(144)}{22.8^{\mathrm{a}}(224)}$ & $\frac{26.4(144)}{21.4^{\mathrm{b}}(224)}$ & $\frac{7.3(41)}{5.9^{\mathrm{d}}(51)}$ \\
& 1 & $14.1(78)$ & $10.4(77)$ & $20.0(10)$ \\
G72 + TAI72 & $\frac{2}{28.7(143)}$ & $\frac{22.6(137)}{18.2^{\mathrm{c}}(224)}$ & $\frac{11.4(35)}{13.3^{\mathrm{c}}(45)}$ \\
& Total & $23.5^{\mathrm{a}(221)}$ & $18.7(75)$ & $6.7(11)$ \\
\hline
\end{tabular}

${ }^{1}$ Cows were treated with the Presynch protocol (2 injections of $\mathrm{PGF}_{2 \alpha} 14 \mathrm{~d}$ apart) and then with 1 of 3 variations of the Ovsynch protocol. Cows were injected with $\mathrm{GnRH}$ at $48 \mathrm{~h}$ after $\mathrm{PGF}_{2 \alpha}$ (G48) and inseminated at 48 (TAI48) or $72 \mathrm{~h}$ (TAI72) after $\mathrm{PGF}_{2 \alpha}$ or injected with GnRH at $72 \mathrm{~h}$ (G72) at the same time as TAI (TAI72).

${ }^{2}$ Conception after first-service treatment TAI.

${ }^{3}$ Calving rate represented the proportion of cows that calved of those cows that conceived to the treatment TAI. Excluded were 12 pregnant cows that were culled before calving.

${ }^{4}$ Pregnancy loss represented the proportion of cows that did not calve of those diagnosed pregnant after the TAI. Excluded were 12 pregnant cows that were culled before calving.

${ }^{\text {aB }}$ oth treatments combined differed $(P<0.05)$ from G72 + TAI72.

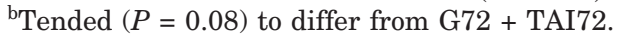

${ }^{\mathrm{c}}$ Different $(P<0.05)$ from G72 + TAI72.

${ }^{\mathrm{d}}$ Different $(P<0.05)$ from G48 + TAI72

had greater pregnancy rates than those with poorer BCS (Moreira et al., 2000b).

Subsequent calving rates for cows that conceived at the treatment TAI also were influenced by treatment (Table 1). Cows in the G72 + TAI 72 treatment tended $(P=0.08)$ to have greater calving rates than $\mathrm{G} 48+$ TAI48 cows and had greater $(P<0.05)$ calving rates than G48 + TAI72 cows.

Pregnancy losses between the treatment TAI and calving differed among treatments (Table 1). Cows in the G48 + TAI48 or G72 + TAI72 treatment had less $(P<0.05)$ pregnancy loss than cows in the G48 + TAI72 treatment. Less pregnancy loss for G48 + TAI48 than G48 + TAI72 is consistent with a previous report (Pursley et al., 1998) in which cows were administered $\mathrm{GnRH}$ and inseminated at comparable times as part of the Ovsynch protocol, but without previous synchronization of estrous cycles (Presynch). Reported losses in our study and those of Pursley et al. (1998) are also consistent with studies reporting greater embryo quality in cows inseminated near the onset of estrus (likely coincident with the GnRH-induced LH surge) than those inseminated at $24 \mathrm{~h}$ after the onset of estrus (Dalton et al., 2001).

\section{General Discussion}

Although cows in the first 2 treatments received the second GnRH injection at similar times (G48), preg- nancy rates were not different. In contrast, cows in the latter treatments were inseminated at similar times (TAI72), but differed in pregnancy rate. Ovulation reportedly occurs between 24 and $34 \mathrm{~h}$ after the second GnRH injection of the Ovsynch protocol (Pursley et al., 1995). Considering the timing of GnRH-induced ovulation, which should be similar for cows injected at G48, regardless of when TAI occurred, pregnancy rates for cows in G48 + TAI72 might be greater than those in G48 + TAI48 because insemination occurred closer to the time of ovulation (Pursley et al., 1998). In contrast, pregnancy rates in our study did not differ between the first 2 treatments.

One would expect more viable sperm with greater fertilizing capacity to be present in the oviduct for G48 + TAI72 cows, because cows inseminated near the onset of estrus (likely similar to cows in which the GnRH-induced LH surge occurred at G48) had more fertilization failure and produced fewer median accessory sperm, resulting in poorer conception (Dalton et al., 2001). Embryo quality (DeJarnette et al., 1992; Nadir et al., 1993) and fertilization rate are related positively to the number of accessory sperm per ovum (Nadir et al., 1993; Saacke et al., 1998, 2000). Considering data from those studies, one may expect that cows on the G48 + TAI48 treatment had poorer fertilization rates and fewer accessory sperm, resulting in fewer viable embryos, than cows inseminated $24 \mathrm{~h}$ 
later (G48 + TAI72). Superovulated Holstein cows inseminated $24 \mathrm{~h}$ after the onset of estrus had greater fertilization rates and more accessory sperm per embryo, whereas embryo quality measured at $6 \mathrm{~d}$ after AI was not affected by time of AI ( 0,12 , or $24 \mathrm{~h}$; Dalton et al., 2000). Furthermore, cows in our study (G48 + TAI48; Table 1) and in single-ovulating cows inseminated at the same time as GnRH injection ( $48 \mathrm{~h}$ after $\mathrm{PGF}_{2 \alpha}$; Pursley et al., 1998) had less pregnancy loss between TAI and calving than cows inseminated at later times after GnRH ( 8 to $32 \mathrm{~h}$ ). Further studies are needed to better understand the relationships between time of insemination and quality and survival of the conceptus.

On the basis of the timing of AI relative to $\mathrm{GnRH}$ induced ovulation, cows on the G48 + TAI72 treatment might be expected to have greater pregnancy rates than cows on the G72 + TAI72 treatment. The opposite was true in the present study, however, resulting in greater pregnancy rates when GnRH injection and TAI occurred concurrently at $72 \mathrm{~h}$ after $\mathrm{PGF}_{2 \alpha}$. Several reasons may account for this improvement: 1) more cows were at the most favorable stages of the estrous cycle at initiation of Ovsynch; 2) exposure to greater concentrations of progesterone (P4) before TAI; 3) increased proportion of cows showing estrus near $72 \mathrm{~h}$ after $\mathrm{PGF}_{2 \alpha}$ injection; 4) a positive effect of the second injection of $\mathrm{GnRH}$ given at $72 \mathrm{~h}$ after $\mathrm{PGF}_{2 \alpha}$, when cows were near the onset of estrus; and 5) greater maturity of the ovulatory follicle and oocyte at the time of ovulation.

As indicated by previous studies, more cows should be expected to initiate the Ovsynch protocol between d 5 to 12 of the estrous cycle (Cartmill et al., 2001a; Moreira et al., 2001; El-Zarkouny et al., 2004) in response to the Presynch injections of $\mathrm{PGF}_{2 \alpha}$. Nearly $70 \%$ of the cows in which estrous cycles were presynchronized initiated the Ovsynch protocol during early to middiestrus compared with $53 \%$ of controls in which Ovsynch was initiated at random stages of the estrous cycle (El-Zarkouny et al., 2004). As a result of presynchronization, pregnancy rates were increased by 10 to 12 percentage points compared with those in Ovsynch controls (Moreira et al., 2001; El-Zarkouny et al., 2004; Navanukraw et al., 2004). For cows in early diestrus (d 5 to 9) at initiation of the Ovsynch protocol, as would be the majority of cows in which estrous cycles were presynchronized, $96 \%$ of the cows ovulated after the first GnRH injection compared with $23 \%$ in which Ovsynch was initiated on 1 to 4 . An increased incidence of ovulation after the first GnRH injection facilitated a greater synchronization rate after $\mathrm{PGF}_{2 \alpha}$ and the greatest incidence of ovulation after the second $\mathrm{GnRH}$ injection (Vasconcelos et al., 1999). In addition, cows receiving a combined Presynch + Ovsynch protocol had greater concentrations of blood $\mathrm{P} 4$ at the time of $\mathrm{PGF}_{2 \alpha}$ injection than those cows receiving Ovsynch at random stages of the estrous cycle (El-Zarkouny et al., 2004; Navanukraw et al., 2004). Greater concentrations of serum $\mathrm{P} 4$ during the period before $\mathrm{PGF}_{2 \alpha}$ injection improved fertility of lactating dairy cows that were subsequently inseminated (Folman et al., 1990; Rosenberg et al., 1990).

Moreover, recent studies in lactating beef cattle (Stevenson et al., 2000; DeJarnette et al., 2001a) and lactating dairy cows (Badinga et al., 1994) reported that the time of estrus after $\mathrm{GnRH}+\mathrm{PGF}_{2 \alpha}$ treatment was approximately $60 \mathrm{~h}$ after $\mathrm{PGF}_{2 \alpha}$. In another study, DeJarnette and Marshall (2003) reported that $65 \%$ of lactating dairy cows that were presynchronized with $2 \mathrm{PGF}_{2 \alpha}$ injections (14 d apart) showed estrus on $\mathrm{d} 3$ after the $\mathrm{PGF}_{2 \alpha}$ injection of Ovsynch, whereas none was observed in estrus before $\mathrm{PGF}_{2 \alpha}$. Our limited observations confirm those in the previous study because $62 \%$ of the cows treated with GnRH at $72 \mathrm{~h}$ were detected on that day (d 3). When these results are considered together, it seems likely that cows receiving Presynch before Ovsynch ovulate later after the $\mathrm{PGF}_{2 \alpha}$ injection, which resulted in the greater pregnancy rates observed for cows on the G72 + TAI72 treatment.

In the present study, we did not include a TAI at $16 \mathrm{~h}$ after $\mathrm{GnRH}$ (optimal time of $\mathrm{AI}$ in the Ovsynch protocol), so it is not known if the G72 + TAI72 treatment might compare favorably with that optimal time of TAI. In a recent study (DeJarnette et al., 2001b), however, application of the Ovsynch protocol without Presynch resulted in overall pregnancy rates of $32 \%$ for cows inseminated concurrent with the $\mathrm{GnRH}$ injection at $72 \mathrm{~h}$ after $\mathrm{PGF}_{2 \alpha}$ (similar timing to our G72 + TAI72 treatment with Presynch) that did not differ from those inseminated 16 to $18 \mathrm{~h}$ after $\mathrm{GnRH}(30 \%)$. Whether presynchronization of estrous cycles before these 2 combinations of $\mathrm{GnRH}$ and TAI timings might change pregnancy outcomes of such treatments has not been determined.

Another factor that may influence the improved reproductive performance of dairy cows inseminated and administered $\mathrm{GnRH}$ at $72 \mathrm{~h}$ after $\mathrm{PGF}_{2 \alpha}$ is the coincidence of GnRH injection and the onset of estrus and the LH surge. Compared with saline-treated controls, administration of $\mathrm{GnRH}$, near or right at the onset of a spontaneous LH surge, produced an LH surge of greater magnitude (Lucy and Stevenson, 1986; Mee et al., 1993; Kaim et al., 2003) or induced a small secondary LH surge (Lucy and Stevenson, 1986), thus decreasing the time from estrus to ovulation and generally improving conception rates (Lucy and Stevenson, 1986; Kaim et al., 2003), although not consistently 
(Tanabe et al., 1994). In addition, cows injected with GnRH at estrus had greater concentrations of serum $\mathrm{P} 4$ after ovulation, for as long as $40 \mathrm{~d}$ after $\mathrm{GnRH}$ in those that became pregnant because of an increase in the ratio of large to small luteal cells in the corpus luteum (CL) (Mee et al., 1993). Greater P4 secretion after ovulation seems to increase embryo survival and improve pregnancy rates in repeat breeder cows injected with GnRH at AI (Mee et al., 1993) or in cows after first AI that subsequently are treated with P4 (ElZarkouny and Stevenson, 2004) or human chorionic gonadotropin (Santos et al., 2001). Cows in the G72 + TAI72 treatment in our experiment were likely near the onset of estrus and, thus, might have benefitted from the $\mathrm{GnRH}$ injection at $72 \mathrm{~h}$ after $\mathrm{PGF}_{2 \alpha}$, resulting in greater pregnancy rates.

Finally, it is possible that more cows in the G72 + TAI72 treatment were inseminated after spontaneously occurring LH surges and ovulation. Delaying the injection of $\mathrm{GnRH}$ until $72 \mathrm{~h}$ after $\mathrm{PGF}_{2 \alpha}(24 \mathrm{~h}$ later than the G48 treatment) may produce larger or more mature follicles at the time of ovulation. Follicle size has been reported to affect subsequent luteal function (Moreira et al., 2000a; Vasconcelos et al., 2001; Peters and Pursley, 2003) and fertility of dairy cows (Vasconcelos et al., 1999, 2001). Ovulation of oocytes from smaller follicles after GnRH injection produced poorer conception, probably because of the subsequent formation of a smaller CL that had a reduced capacity for P4 biosynthesis (Moreira et al., 2000a; Vasconcelos et al., 2001). In contrast, lactating dairy cows ovulating oocytes from smaller follicles had greater pregnancy rates than those cows ovulating from larger follicles (Vasconcelos et al., 1999).

The most plausible explanation for improved pregnancy rates resulting from the G72 + TAI72 treatment is that the ovulatory follicle and its oocyte are more mature at the time of fertilization than those of cows in the other treatments (G48). The G72 + TAI72 treatment is likely allowing for optimal development of the preovulatory follicle before $\mathrm{GnRH}$ is administered at $72 \mathrm{~h}$ after $\mathrm{PGF}_{2 \alpha}$. Cows in which estrous cycles are presynchronized likely have more uniform follicle development with fewer cows coming into estrus at 24 or $48 \mathrm{~h}$ after $\mathrm{PGF}_{2 \alpha}$. Thus, programmed follicle development in the presence of a CL to the time of the $\mathrm{PGF}_{2 \alpha}$ injection allows the G72 + TAI72 treatment to increase pregnancy rates in cows previously exposed to the Presynch protocol. In addition, prolonging the time between $\mathrm{PGF}_{2 \alpha}$-induced $\mathrm{CL}$ regression and the $\mathrm{LH}$ surge seems to increase pregnancy rates after TAI (Peters and Pursley, 2003). This begs the question whether the GnRH injection is necessary when inseminating at $72 \mathrm{~h}$ after Presynch + Ovsynch because of the likely greater synchrony resulting from more cows in early to middiestrus at the onset of the Ovsynch protocol. Further research is needed to answer that question.

\section{CONCLUSIONS}

In our study, in which estrous cycles of lactating cows were presynchronized (Presynch), inseminating cows at 48 or $72 \mathrm{~h}$ after $\mathrm{PGF}_{2 \alpha}$, when GnRH was administered at $48 \mathrm{~h}$ after $\mathrm{PGF}_{2 \alpha}$, produced poorer pregnancy and calving rates than injecting $\mathrm{GnRH}$ and inseminating cows at $72 \mathrm{~h}$ after $\mathrm{PGF}_{2 \alpha}$. The latter treatment allows for time and labor savings because cows are handled one less time than with the standard Ovsynch protocol in which the second GnRH injection and TAI are not concurrently done. Further, all injections and the TAI can be performed at the same time each day (a.m. or p.m.) when cows are restrained in feed-line lockups.

Moreover, pregnancy rates of cows inseminated and injected with $\mathrm{GnRH}$ at $72 \mathrm{~h}$ after $\mathrm{PGF}_{2 \alpha}$ likely would be improved if cows expressing estrus before their scheduled TAI are inseminated on the basis of detected estrus. The remaining cows could then be injected with $\mathrm{GnRH}$ and inseminated at $72 \mathrm{~h}$. This TAI would serve as a clean-up insemination for cows not previously detected in estrus and inseminated. Thus, fewer GnRH injections per pregnancy may be required.

Our study did not define whether the G72 + TAI72 treatment provides an acceptable time to inseminate cows when applying only the Ovsynch protocol. Our unpublished results (Portaluppi and Stevenson, unpublished data) in which we have administered the same treatments (no Presynch) to cows found not pregnant at pregnancy diagnosis revealed that the G72 + TAI72 treatment is not likely to be ideal $(19.1 \%$; $\mathrm{n}=$ 138) compared with G48 + TAI48 $(24.3 \%$; $n=141)$ or G48 + TAI72 (27.4\%; $\mathrm{n}=141)$ treatments. Additional studies should be conducted to determine the time of estrus and ovulation after Presynch + Ovsynch protocol to better understand whether the proposed timing (TAI72) of AI is near optimal.

\section{ACKNOWLEDGMENTS}

The authors thank Meier Dairy (Palmer, KS) and Ohlde Dairy (Linn, KS) for participating in this study and allowing us to use their cattle and facilities to conduct this experiment.

\section{REFERENCES}

Badinga, L., W. W. Thatcher, C. J. Wilcox, G. Morris, K. Entwistle, and D. Wolfenson. 1994. Effect of season on follicular dynamics and plasma concentrations of estradiol-17 $\beta$, progesterone and 
luteinizing hormone in lactating Holstein cows. Theriogenology 42:1263-1274.

Burke, J. M., R. L. de la Sota, C. A. Risco, C. R. Staples, É. J.-P. Schmitt, and W. W. Thatcher. 1996. Evaluation of timed insemination using a gonadotropin-releasing hormone agonist in lactating dairy cows. J. Dairy Sci. 79:1385-1393.

Cartmill, J. A., S. Z. El-Zarkouny, B. A. Hensley, G. C. Lamb, and J. S. Stevenson. 2001a. Stage of cycle, incidence, and timing of ovulation, and pregnancy rates in dairy cattle after three timed breeding protocols. J. Dairy Sci. 84:1051-1059.

Cartmill, J. A., S. Z. El-Zarkouny, B. A. Hensley, T. G. Rozell, J. F. Smith, and J. S. Stevenson. 2001b. An alternative AI breeding protocol for dairy cows exposed to elevated ambient temperatures before or after calving or both. J. Dairy Sci. 84:799-806.

Dalton, J. C., S. Nadir, J. H. Bame, M. Noftsinger, and R. G. Saacke. 2000. The effect of time of artificial insemination on fertilization status and embryo quality in superovulated cows. J. Anim. Sci. 78:2081-2085.

Dalton, J. C., S. Nadir, J. H. Bame, M. Noftsinger, R. L. Senger, and R. G. Saacke. 2001. Effect of time of insemination on number of accessory sperm, fertilization rate, and embryo quality in nonlactating dairy cattle. J. Dairy Sci. 84:2413-2418.

DeJarnette, J. M., M. L. Day, R. B. House, R. A. Wallace, and C. E. Marshall. 2001a. Effect of GnRH pretreatment on reproductive performance of postpartum suckled beef cows following synchronization of estrus using $\mathrm{GnRH}$ and $\mathrm{PGF}_{2 \alpha}$. J. Anim. Sci. 79:1675-1682.

DeJarnette, J. M., and C. E. Marshall. 2003. Effects of presynchronization using combinations $\mathrm{PGF}_{2 \alpha}$ and (or) $\mathrm{GnRH}$ on pregnancy rates of Ovsynch-and Cosynch-treated lactating Holstein cows. Anim. Reprod. Sci. 77:51-60.

DeJarnette, J. M., R. G. Saacke, J. Bame, and C. J. Vogler. 1992 Accessory sperm: Their importance to fertility and embryo quality, and attempts to alter their numbers in artificially inseminated cattle. J. Anim. Sci. 70:484-491.

DeJarnette, J. M., R. R. Salverson, and C. E. Marshall. 2001b. Incidence of premature estrus in lactating dairy cows and conception rates to standing estrus or fixed-time inseminations after synchronization using $\mathrm{GnRH}$ and $\mathrm{PGF}_{2 \alpha}$. Anim. Reprod. Sci. 67:27-35.

El-Zarkouny, S. Z., J. A. Cartmill, B. A. Hensley, and J. S. Stevenson. 2004. Pregnancy in dairy cows after synchronized ovulation regimens with or without presynchronization and progesterone. J. Dairy Sci. 87:1024-1037.

El-Zarkouny, S. Z., and J. S. Stevenson. 2004. Resynchronization of estrus with progesterone or progesterone plus estrogen in lactating dairy cows of unknown pregnancy status. J. Dairy Sci. 87:3306-3321.

Folman, Y., M. Kaim, Z. Herz, and M. Rosenberg. 1990. Comparison of methods for the synchronization of estrous cycles in dairy cows. 2. Effects of progesterone and parity on conception. J. Dairy Sci. 73:2817-2825.

Jobst, S. M., R. L. Nebel, M. L. McGilliard, and K. D. Peizer. 2000. Evaluation of reproductive performance in lactating dairy cows with prostaglandin $\mathrm{F}_{2 \alpha}$, gonadotropin-releasing hormone, and timed artificial insemination. J. Dairy Sci. 83:2366-2372.

Kaim, M., A. Bloch, D. Wolfenson, R. Braw-Tal, M. Rosenberg, H. Voet, and Y. Folman. 2003. Effects of GnRH administered to cows at the onset of estrus on timing of ovulation, endocrine responses, and conception. J. Dairy Sci. 86:2012-2021.

Lucy, M. C. 2001. Reproductive loss in high-producing dairy cattle: Where will it end? J. Dairy Sci. 84:1277-1293.

Lucy, M. C., and J. S. Stevenson. 1986. Gonadotropin-releasing hormone at estrus: Luteinizing hormone, estradiol, and progesterone during the periestrual and postinsemination periods in dairy cattle. Biol. Reprod. 35:300-311.

Mee, M. O., J. S. Stevenson, B. M. Alexander, and R. G. Sasser. 1993. Administration of GnRH at estrus influences pregnancy rates, serum concentrations of $\mathrm{LH}, \mathrm{FSH}$, estradiol-17 $\beta$, pregnancy-specific protein $B$, and progesterone, proportion of luteal cell types, and in vitro production of progesterone in dairy cows. J. Anim. Sci. 71:185-198.
Moreira, F., R. L. de la Sota, T. Diaz, and W. W. Thatcher. 2000a. Effect of day of the estrous cycle at the initiation of a timed artificial insemination protocol on reproductive responses in dairy heifers. J. Anim. Sci. 78:1568-1576.

Moreira, F., C. Orlandi, C. A. Risco, R. Mattos, F. Lopes, and W. W. Thatcher. 2001. Effects of presynchronization and bovine somatotropin on pregnancy rates to a timed artificial insemination protocol in lactating dairy cows. J. Dairy Sci. 84:1646-1659.

Moreira, F., C. Risco, M. F. A. Pires, J. D. Ambrose, M. Drost, M. DeLorenzo, and W. W. Thatcher. 2000b. Effect of body condition on reproductive efficiency of lactating dairy cows receiving a timed insemination. Theriogenology 53:1305-1319.

Nadir, S., R. G. Saacke, J. Bame, J. Mullins, and S. Degelos. 1993. Effect of freezing semen and dosage of sperm on number of accessory sperm, fertility, and embryo quality in artificially inseminated cattle. J. Anim. Sci. 71:199-204.

Navanukraw, C., D. A. Redmer, L. P. Reynolds, J. D. Kirsch, A. T. Grazul-Bilska, and P. M. Fricke. 2004. A modified presynchronization protocol improves fertility to timed artificial insemination in lactating dairy cows. J. Dairy Sci. 87:1551-1557.

Peters, M. W., and J. R. Pursley. 2003. Timing of final GnRH of the Ovsynch protocol affects ovulatory follicle size, subsequent luteal function, and fertility in dairy cows. Theriogenology 60:1197-1204.

Pursley, J. R., M. R. Kosorok, and M. R. Wiltbank. 1997a. Reproductive management of lactating dairy cows using synchronization of ovulation. J. Dairy Sci. 80:301-306.

Pursley, J. R., M. E. Lee, and M. C. Wiltbank. 1995. Synchronization of ovulation in dairy cows using $\mathrm{PGF}_{2 \alpha}$ and GnRH. Theriogenology $44: 915-923$.

Pursley, J. R., R. W. Silcox, and M. C. Wiltbank. 1998. Effect of time of artificial insemination on pregnancy rates, calving rates, pregnancy loss, and gender ratio after synchronization of ovulation in lactating dairy cows. J. Dairy Sci. 81:2139-2144.

Pursley, J. R., M. C. Wiltbank, J. S. Stevenson, J. S. Ottobre, H. A. Garverick, and L. L. Anderson. 1997b. Pregnancy rates per artificial insemination for cows and heifers inseminated at a synchronized ovulation or synchronized estrus. J. Dairy Sci. 80:295-300.

Rosenberg, M., M. Kaim, Z. Herz, and Y. Folman. 1990. Comparison of methods for the synchronization of estrous cycles in dairy cows. 1. Effects on plasma progesterone and manifestation of estrus. J. Dairy Sci. 73:2807-2816.

Saacke, R. G., J. C. Dalton, S. Nadir, R. L. Nebel, and J. H. Bame. 2000. Relationships of seminal traits and insemination time to fertilization rate and embryo quality. Anim. Reprod. Sci. 606:663-677.

Saacke, R. G., J. M. DeJarnette, J. H. Bame, D. S. Karanbinus, and S. S. Whitman. 1998. Can spermatozoa with abnormal heads gain access to the ovum in artificially inseminated super- and single ovulating cattle? Theriogenology 50:117-128.

Santos, J. E., W. W. Thatcher, L. Pool, and M. W. Overton. 2001. Effect of human chorionic gonadotropin on luteal function and reproductive performance of high-producing lactating Holstein dairy cows. J. Dairy Sci. 79:2881-2894.

Senger, P. L. 1994. The estrus detection problem: New concepts, technologies, and possibilities. J. Dairy Sci. 77:2745-2753.

Stevenson, J. S., Y. Kobayashi, and K. E. Thompson. 1999. Reproductive performance of dairy cows in various programmed breeding systems including Ovsynch and combinations of gonadotropinreleasing hormone and prostaglandin $\mathrm{F}_{2 \alpha}$. J. Dairy Sci. 82:506-515.

Stevenson, J. S., M. K. Schmidt, and E. P. Call. 1983. Estrous intensity and conception rates in Holsteins. J. Dairy Sci. 66:275-280.

Stevenson, J. S., K. E. Thompson, W. L. Forbes, G. C. Lamb, D. M. Grieger, and L. R. Corah. 2000. Synchronizing estrus and (or) ovulation in beef cows after combinations of $\mathrm{GnRH}$, norgestomet, and prostaglandin $\mathrm{F}_{2 \alpha}$ with or without timed insemination. J. Anim. Sci. 78:1747-1758.

Tanabe, T. Y., D. R. Deaver, and H. W. Hawk. 1994. Effect of gonadotropin-releasing hormone on estrus, ovulation, and ovum cleavage rates of dairy cows. J. Anim. Sci. 72:719-724. 
Tenhagen, B. A., R. Surholt, M. Wittke, C. Vogel, M. Drillich, and W. Heuwieser. 2004. Use of Ovsynch in dairy herds-Differences between primiparous and multiparous cows. Anim. Reprod. Sci. 81:1-11.

Vasconcelos, J. L., R. Sartori, H. N. Oliveira, J. G. Guenther, and M. C. Wiltbank. 2001. Reduction in size of ovulatory follicle reduces subsequent luteal size and pregnancy rate. Theriogenology $56: 307-314$.

Vasconcelos, J. L. M., R. W. Silcox, J. R. Pursley, and M. C. Wiltbank. 1999. Synchronization rate, size of ovulatory follicle, and preg- nancy rate after synchronization of ovulation beginning on different days of the estrous cycle in lactating dairy cows. Theriogenology 52:1067-1078.

Washburn, S. P., W. J. Silvia, C. H. Brown, B. T. McDaniel, and A. J. McAllister. 2002. Trends in reproductive performance in southeastern Holstein and Jersey DHI herds. J. Dairy Sci. 85:244-251.

Yamada, K., T. Nakao, and N. Isobe. 2003. Effects of body condition score in cows peripartum on the onset of postpartum ovarian cyclicity and conception rates after ovulation synchronization/ fixed-time artificial insemination. J. Reprod. Dev. 49:381-388. 